Document downloaded from:

http://hdl.handle.net/10251/92547

This paper must be cited as:

Aleixandre Benavent, JL.; Aleixandre Tudó, JL.; Bolaños-Pizarro, M.; Aleixandre Benavent, R. (2016). Viticulture and oenology scientific research: The Old World versus the new World wine-producing countries. International Journal of Information Management. 36(3):389-396. doi:10.1016/j.ijinfomgt.2016.01.003

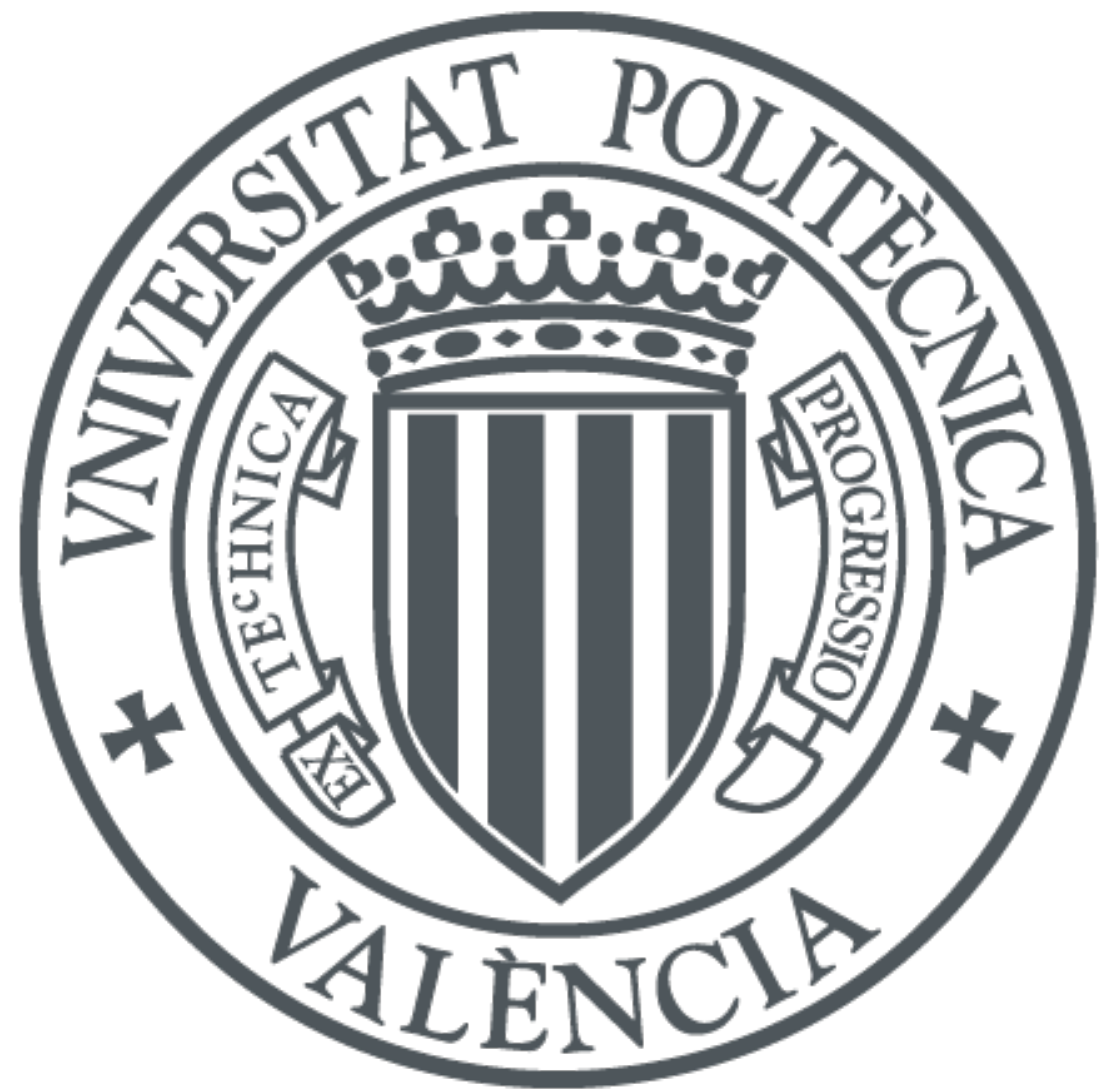

The final publication is available at

http://doi.org//10.1016/j.ijinfomgt.2016.01.003

Copyright Elsevier

Additional Information 
Elsevier Editorial System(tm) for International Journal of Information Management Manuscript Draft

Manuscript Number: IJIM-D-15-00044

Title: Viticulture and oenology scientific research: the old world versus the new world wine-producing countries.

Article Type: Research Paper

Keywords: Scientific productivity, viticulture and oenology, wine-producing countries, Old World, New World.

Corresponding Author: Prof. José Luis Aleixandre, Ph. D. Agricultural Engineer

Corresponding Author's Institution: Politecnic University of Valencia (Spain)

First Author: José Luis Aleixandre, Ph. D. Agricultural Engineer

Order of Authors: José Luis Aleixandre, Ph. D. Agricultural Engineer

Abstract: The main aim of this study was to analyze the scientific productivity and collaboration between Old world wine-producing countries (Austria, Bulgaria, France, Germany, Greece, Hungary, Italy, Portugal, Romania, Spain, Switzerland) and new world wine-producing countries (Argentina, Australia, Brazil, Canada, Chile, Mexico, New Zealand, Peru, South Africa, United Sates, Uruguay) in viticulture and oenology through bibliometric analyses of articles included in the Science Citation Index Expanded database for the period 1994-2013. A number of 1,527 research articles were published in 563 journals. The results highlight an important growth in the collaboration between countries during the second decade (2004-2013). Papers have been published in numerous journals belonging to several subject areas. Food Science and Technology, Horticulture and Biotechnology and Applied Microbiology appeared as the most productive research areas. A social network analysis of collaboration between these countries was also performed in order to analyse the most powerful scientific cooperation.

This is an interesting and unusual paper. There are some typographical errors which need attention. I think the paper would be enhanced by a deeper consideration of the use of VOSviewer as this is integral to developing the representations of the research networks. Also I think information management issues associated with the research needs to be properly highlighted for example why information management can be enhanced by a proper analysis of the development of research networks. 


\section{COVER LETTER}

\section{"Viticulture and oenology scientific research: the old world versus the new world wine-producing countries."}

The wines elaborated in the old world are those produced in regions with a long documented wine history production. These wines are considered to be from different European and Mediterranean regions. On the other hand the new world wines are those coming from countries outside Europe. Noticeable differences, different from the long tradition of the wine production, between old world wines and new world wines exist. Differences in terroir, varieties, winemakers, brand policies and designations of origin have been widely identified. Moreover, old and new world wine countries consumers seem to evaluated wines differently.

Throughout the past three decades, the global pattern of wine production has undergone fundamental changes, most notably the emergence of new world producers. Over time only a few new world wine producers developed trade and scientific collaboration networks that resemble those of traditional old world producers. Also the structures of trade and scientific collaboration networks are more established for old world producing countries than in new world producers, which suggests that it are particularly the first ones who may have mainly benefited from participation in international scientific collaboration.

On the other hand the impact of globalisation on the wine industry is characterised by: rapidly growing and evolving international markets, the expansion of new world wines on international markets, and the response of old world competitors to new world competition. Scientific collaboration facilitates the flow of information among researchers and also allows for cost-sharing and improved efficiency in research.

The aim of this study was thus to analyze the collaborative research between old world and new world researchers in viticulture and oenology through bibliographic analyses of articles in the Science Citation Index Expanded (SCI-E) database for the 1994 to 2013 period. The length of this time period allows us to obtain comprehensive information with which establish trends in the research fields. Moreover, the combined analysis of productivity, collaboration and scientific impact will provide a global and integrated vision of the countries' research in this area.

Authors:

1. José Luis Aleixandre

- Professor of Universidad Politécnica of Valencia

- Camino de Vera, s/n 46022 Valencia (Spain)

- e-mail: jaleixan@tal.upv.es

- Cell phone: +34 625978549

2. José Luis Aleixandre Tudó

- Research Technician of Universidad Politécnica of Valencia

- Camino de Vera, s/n 46022 Valencia (Spain)

- e-mail: joaltu@upvnet.upv.es

- Cell phone: +34 695462285

3. Máxima Bolaños Pizarro

- Assistant Professor of Universidad of Valencia

- Plaza Cisneros, 446003 Valencia (Spain)

- e-mail: máxima.bolanos@uv.es

- Cell phone: +34 687185484 
4. Rafael Aleixandre Benavent (corresponding author)

- Researcher of Spanish Research Council

- Plaza Cisneros, 446003 Valencia (Spain)

- e-mail: Rafael.Aleixandre@uv.es

- Cell phone: +34 697881288

Authors contributions :

1. José Luis Aleixandre was the project leader

2. José Luis Aleixandre-Tudó was responsible of the Viticulture and Oenology information.

3. Máxima Bolaños was responsible of the statistical treatment

4. Rafael Aleixandre-Benavent searched and reviewed the literature 
Tittle: Viticulture and oenology scientific research: the old world versus the new world wine-producing countries.

\section{HIGHLIGHTS}

1. Study of collaborative research between old and new world wine producing countries.

2. Significant growth in the number of research papers published from 1994 to 2013.

3. All countries have USA as the main country with which collaborated. 
Viticulture and oenology scientific research: the old world versus the new world wine-producing countries.

José Luis Aleixandre ${ }^{1}$, José Luis Aleixandre-Tudó ${ }^{1}$, Máxima Bolaños-Pizarro ${ }^{2}$ and Rafael Aleixandre-Benavent ${ }^{3}$

1 - Professor of Universidad Politécnica of Valencia

- Camino de Vera, s/n

- 46022 Valencia (Spain)

- e-mail: jaleixan@tal.upv.es

- Cell phone: +34 625978549 Fax: +34 963877369

1 - Posdoctoral Research Felow of Universidad Politécnica of Valencia

- Camino de Vera, s/n

- 46022 Valencia (Spain)

- e-mail: joaltu@upvnet.upv.es

- Cell phone: +34 695462285 Fax: +34 963877369

2 - Assistant Professor of Universidad Carlos III

- Avenida de la Universidad, 30

- 28911 Leganés (Madrid) Spain

- e-mail: mabopi@gmail.com

- Cell phone: +34 687185484 Fax: +34 916249597

3 - Researcher of Spanish Research Council

- Instituto de Historia de la Medicina y de la Ciencia López Piñero. UISYS

(CSIC-Universidad de Valencia)

- Plaza Cisneros, 4

- 46003 Valencia (Spain)

- e-mail: $\underline{\text { rafael.aleixandre@uv.es }}$

- Cell phone: +34 697881288 Fax: +34963919691

${ }^{1}$ Corresponding author: jaleixan@tal.upv.es 


\title{
Viticulture and oenology scientific research: the old world versus the new world wine-producing countries.
}

José Luis Aleixandre ${ }^{1}$, José Luis Aleixandre-Tudó ${ }^{1}$, Máxima Bolaños-Pizarro ${ }^{2}$ and Rafael Aleixandre-Benavent ${ }^{3}$

\begin{abstract}
The main aim of this study was to analyze the scientific productivity and collaboration between Old world wine-producing countries (Austria, Bulgaria, France, Germany, Greece, Hungary, Italy, Portugal, Romania, Spain, Switzerland) and new world wineproducing countries (Argentina, Australia, Brazil, Canada, Chile, Mexico, New Zealand, Peru, South Africa, United Sates, Uruguay) in viticulture and oenology through bibliometric analyses of articles included in the Science Citation Index Expanded database for the period 1994-2013. A number of 1,527 research articles were published in 563 journals. The results highlight an important growth in the collaboration between countries during the second decade (2004-2013). Papers have been published in numerous journals belonging to several subject areas. Food Science and Technology, Horticulture and Biotechnology and Applied Microbiology appeared as the most productive research areas. A social network analysis of collaboration between these countries was also performed in order to analyse the most powerful scientific cooperation.
\end{abstract}

Key words: Scientific productivity, viticulture and oenology, wine-producing countries, Old World, New World.

\section{Introduction}

The wines 1 borated in the old world are those produced in regions with a long documented wine history production. These wines are considered to be from different European and Mediterranean regions. These regions include: Austria, Bulgaria, Spain, France, Greece, Hungary, Italy, Portugal, Romania and Switzerland as the most important countries. On the other hand the new world wines are those coming from countries outside Europe, such as: Argentina, Chile, USA, Mexico, Peru, Canada, Australia, New Zealand, South Africa, Brazil and Uruguay (Anderson, 2003; Robinson, 2006).

Noticeable differences, different from the long tradition of the wine production, between old world wines and new world wines exist. Differences in terroir, varieties, winemakers, brand policies and designations of origin have been widely identified (Lao,

\footnotetext{
${ }^{1}$ Corresponding author: jaleixan@tal.upv.es
} 
2009). New world wines are appreciated by different attributes than those found in the wines produced in the old world wine ${ }_{0}$ ducing countries. Moreover, old and new world wine countries consumers seem to evaluated wines differently (Lecoq \& Visser, 2006; Schamel, 2006; Benfratello, Piacenza, \& Sacchettos, 2009; Carew and Florkowski, 2010; Parcero and Villanueva, 2011; Yoo, Florkwski, \& Crew, 2011).

Throughout the past three decades, the global pattern of wine production has undergone fundamental changes, most notably the emergence of new world producers. Over time only a few new world wine producers developed trade and scientific collaboration networks that resemble those of traditional old world producers. Also the structures of trade and scientific collaboration networks are more establishe $f$ r old world producing countries than in new world producers, which suggests that it are particularly the first ones who may have mainly benefited from participation in international scientific collaboration (Aylward, 2003; Brow, Derudder, Parnreiter, Pelupessy, Taylor, \& Witlox, 2010; Cassi, Morrison, \& Rabellotti, 2011).

Wine is an integral part of the so-called old world nations, amalgamating with the local history and landscape, and providing a powerful "origin branding". To date, however, these dimensions have been discussed to a very limited extent in emerging new world wine regions where the lack of a traditional heritage of wine making presents special challenges in terms of origin branding (Gil \& Sánchez, 1997; Beverland, 2006; Bramley \& Kirsten, 2007; Perrouty, d’Hauteville, \&Lockshin, 2007; Duarte \& Northcote, 2009).

On the other hand the impact of globalisation on the wine industry is characterised by: rapidly growing and evolving international markets, the expansion of new world wines on international markets, and the response of old world competitors to new world competition (Anderson, Norman, \& Wittwer, 2003; Campbell \& Guibert, 2006; Archibugi, 2007).

Scientific collaboration facilitates the flow of information among researchers and also allows for cost-sharing and improved efficiency in research (Katz \& Martin, 1997; Newman, 2004). One way to determine the level of established cooperation is to count the number of co-authorships in an area of scientific research. The co-authorship relationship occurs when two or more authors or institutions contribute to the same scientific paper (Newman, 2004). Using social network analysis, these interpersonal and inter-institutional collaborations can be represented by graphs that quantify how many members make up a network, the intensity of their relationships and which members are the most relevant (Newman, 2004; González-Alcaide, Aleixandre-Benavent, Navarro Molina, \& Valderrama-Zurián, 2008a). Researchers with the largest number of collaborative publications are at the "research front' of that field (González-Alcaide, Alonso rroyo, gonzález de Dios, Pérez Sampere, Valderrama-Zurián, \& AleixandreBenavent, 2008b).

The aim of this study was thus to analyze the collaborative research between old world and new world researchers in viticulture and oenology through bibliographic analyses of articles in the Science Citation Index Expanded (SCI-E) database for the 1994 to 2013 
period. The period allows us to obtain comprehensive information with which establish trends in the research fields. Moreover, the combined analysis of productivity, collaboration and scientific impact will provide a global and integrated vision of the countries' research in this area.

\section{Materials and methods}

The articles used for analysis were obtained from the Science Citation Index Expanded (SCIE) database, which was accessed via the Web of Knowledge platform. Only papers categorized as articles or reviews were considered; sources such as letters, editorial material, book reviews, proceedings, reprints, news and bibliographic articles were excluded.

To research publications in the field of "wine research", we used a strategy consisting of several components (Glanzel \& Veugelers, 2006; Aleixandre, Aleixandre-Tudó, Bolaños-Pizarro, \& Aleixandre-Benavent, 2013): a) searches by specific words, b) searches by institutional addresses, c) searches in specific viticulture and enology journals, d) searches involving old world countries and new world countries, e) searches limited to a 20-year period.

a) For the searches involving specific words, we used the following terms:

$\mathrm{TS}=($ grapevin* or wines or "wine grap*" or "wine pro*" or "red wine*" or "white wine*" or winemaking or enolog* or viticult* or oenolog* or "wine cell*" or "wine yeast*" or winery or wineries). TS means the label for the field "topic", and records are retrieved if the above terms are included in the titles, keywords or abstracts of articles. Some roots were cut with an asterisk to obtain all of the documents associated with the derived words (e.g., by searching for enolog*, the SCIE database finds enology, enologist, enological, etc.).

b) For the searches for institutional addresses, we used the following terms:

$\mathrm{AD}=($ enolog* or viticult* or oenol*), where $\mathrm{AD}$ is the label for the institutional addresses of the authors.

c) For the searches in specific viticulture and enology journals, we used:

$\mathrm{SO}=$ American Journal of Enology and Viticulture or Australian Journal of Grape and Wine Research or Ciencia e Técnica Vitivinícola or Journal International des Sciences de la Vigne et du Vin or South African Journal of Enology and Viticulture or VITIS. SO is the label for the name of the journal.

d) For the search limited to articles that were authored in old world and new world countries, we used the following: 
$\mathrm{CU}=$ (Austria, Bulgaria, France, Germany, Greece, Hungary, Italy, Portugal, Romania, Spain, Switzerland) AND CU= (Argentina, Australia, Brazil, Canada, Chile, Mexico, New Zealand, Peru, South Africa, United Sates, Uruguay). CU is the label for the name of the country.

e) Finally, the analysis was limited to a 20-year period, 1994 to 2013.

The searches using specific words, institutions and journals $(a, b, c)$ were combined with the logical operator "or". These results were combined with countries (d) and time period (e) using the "and" operator. Searches were performed on 1/04/2014.

The records obtained were exported to a relational database in Microsoft Access. The information was analyzed to obtain bibliometric indicators of scientific productivity, patterns of collaboration, number of citations and impact. A social network analysis was also carried out to identify the number of co-occurrences between countries, i.e., all combinations of pairs of countries on each paper. The software Pajek (Batagelj and Mrvar, 2001) was used to construct and graphically represent the research groups and to visualize the networks. The software VOSViewer was used for the construction of the network of collaboration among countries. Data on impact factor were extracted from the 2012 edition of the Journal Citation Reports (JCR).

\section{Results}

During the two decades (1994-2013) 1,527 papers in collaboration, 1,433 (94\%) articles and 94 reviews $(6 \%)$ were published. The number of published articles has increased steadily from 1994, when 22 articles (1.4\%) were published, until 2013 with 164 $(10.7 \%)$ published articles. Moreover most of the articles were published in the second decade (74\% versus 26\%) (Figure 1).

\section{Insert Figure 1}

Papers have been published in 563 different journals, being the most productive the Journal of Agricultural and Food Chemistry $(\mathrm{n}=103)$, followed by the American Journal of Enology and Viticulture $(\mathrm{n}=71)$ and VITIS $(\mathrm{n}=48)$ (Table 1). Other specific journals in viticulture and enology were: Australian Journal of Grape and Wine Research (N=28), Journal International des Sciences de la Vigne et du Vin $(\mathrm{N}=26)$ and South African Journal of Enology and Viticulture $(\mathrm{n}=9)$.

Insert Table 1 
Food Science \& Technology (FST) is the subject area with the highest number of published articles $(n=430)$, followed by Horticulture $(n=222)$ and Biotechnology \& Applied Microbiology ( $\mathrm{n}=208)$ (Table 2). The most productive journals in FST have been Journal of Agricultural and Food Chemistry, American Journal of Enology and Viticulture and Food Chemistry. In the subject area of Horticulture journals devoted specifically to enology and viticulture are the most common. In the subject area Biotechnology \& Applied Microbiology stands out the American Journal of Enology and Viticulture and also specific microbiology journals. The most frequent keywords are related with red wines, Vitis-vinifera, identification, Saccharomyces-cerevisae, Arabidopsis-thaliana, strains and fermentations, among others. Regarding the countries leading the publications in each area, USA is the country with the most articles in all areas except FST, where France ranks first, and Applied Chemistry, where this position is occupied by Spain. Other represented countries are Italy and Australia.

Insert Table 2

Table 3 shows the total number of published papers by each country, the papers written in collaboration between old world and new world wine-producing countries and the percentage of papers in collaboration. Old world most productive countries were Spain $(n=4,786)$, Italy $(n=3,791)$ and France $(n=3,699)$. New World most productive countries were United States $(n=5,837)$, Australia $(n=1,973)$ and Brazil $(n=1,089)$. Regarding the collaboration, the figures were as follows. The country with which the old world countries have collaborated the most is United States, highlighting collaborations with Italy $(n=235)$, France $(n=193)$, Germany $(n=128)$ and Spain $(n=117)$. Other important collaborations were found between Australia and France $(n=98)$, Australia and Italy $(n=53)$ and Argentina and Spain $(n=51)$. The higher percentage of collaborating papers in the old world countries was found in Hungary (18.4\%) followed by Germany (14.4\%) and France (14.3\%). Percentages of collaboration in new world countries are higher than in old world countries, highlighting Peru (56.3\%), Uruguay (37.6\%) and Mexico (35,2\%).

Insert Table 3

The network of collaboration between the 22 countries is drawn in Figure 2. The thickness of the spheres is proportional to the number of papers written in collaboration by each country. The thickness of the lines connecting two countries is proportional to the number of papers published in cooperation between the two countries. USA occupies a central position in the network, where also appears highlighted France, Italy, Spain, Germany and Australia. 
Insert Figure 2

Figure 3 correlates the number of published papers and the number of received citations in the two groups of countries. In the new world countries a correlation exists between the total number of scientific papers published by each country and citations in all scientific areas and the number of papers published in viticulture and oenology. The only exception is Canada, with fewer papers in viticulture and oenology than those expected. Regarding old world countries, there are also correlations between these numbers, with the exception of Germany, a country in which there is no correlation between the total production of scientific papers and the number of papers viticulture and oenology.

Insert Figure 3

Papers with more than 200 citations are shown in Table 4. Two papers are highlighted with more than 2,000 citations. The most cited paper, entitled "Cancer chemopreventive activity of resveratrol, a natural product derived from grapes", was published in 1997 in the journal Science and has received 2,644 citations. This paper was written in collaboration between three different departments, at the University of Illinois (Chicago, USA) and also with the Universidad Complutense de Madrid (Spain). The second paper, with 2,348 citations, entitled "Analysis of total phenols and other oxidation substrates and antioxidants by means of Folin-Ciocalteu reagent", was published in 1999 in the journal Oxidants and Antioxidants. This paper was written in collaboration between institutions from three different countries: University of California (Davis, USA), Austrian Institute of Technology (Seibersdorf, Austria) and University of Barcelona (Spain).

Inset Table 4

\section{Discussion}

This study provides a bibliometric analysis of collaborative research on wine and grapes by old world and new world wine-producing countries. This work showed that the scientific collaboration in viticulture and oenology between these countries has been steadily increased during the past 20 years. This growth took place mainly in the decade 
comprising the years from 2004 to 2013. Increasing number of international collaborations was also observed throughout the study period. These results point out a positive trend, which indicates an increase in the research collaboration in the area. One of the main reasons that explain these findings could be the need for increased international cooperation between countries. Collaboration between countries would be required in order to achieve improved research results. (Katz \& Martin, 1997; Newman, 2004). Encouraging the development of research networks which bring together scientists from different countries would thus be a key role strategy for cooperation. These research groups enhance knowledge, improve quality, and increase innovation and competitiveness (Cunningham \& Dillon, 1997; Aleixandre-Benavent, AleixandreTudó, González Alcaide, \& Aleixandre, 2013).

The research papers have been published in numerous journals specialized in several subject areas such as for example FST. This includes specific journals in the areas of viticulture and enology, horticulture, biotechnology and applied microbiology, plant sciences, etc. This diversity is consistent with the multidisciplinary nature of the subject that favours the existence of extensive collaborations and synergies between viticulture and enology and other disciplines (Glanzel \& Veugelers, 2006; Aleixandre, AleixandreTudó, Bolaños-Pizarro, \& Aleixandre-Benavent, 2013).

As we have observed, five countries are leading publications in all areas: United States, France, Spain, Italy and Australia. United States stands out strikingly on the new world countries due to their greater scientific productivity. Regarding old world countries the productivity is led by Spain, but closely followed by Italy and France. These findings could be explained by the logical reasoning that is based in the large wine production industry which is accompanied by the subsequent increased research productivity (Aleixandre-Benavent, Aleixandre-Tudó, González Alcaide, \& Aleixandre, 2013).

The highest percentage of papers published in collaboration corresponds to Latin American new world countries, especially Peru, Uruguay, Mexico and Argentina. For these countries, collaboration with the scientific elite nations such as the United States or the European countries is essential, because this enables researchers, lecturers and students to exchange with their international colleagues the latest scientific developments allowing them to gain access to the best equipment, facilities, and talent, and therefore to participate in large-scale research projects that are beyond the financial capabilities of individual countries (Glänzel \& Veugelers, 2006; Glanzel, 2001; Subramanyam, 1983; Luukkonen, Persson, \& Sivertsen, 1992). Research-based collaboration includes joint research activities, technology co-development, contract research, and technology exchange. The promotion of these research opportunities in foreign centers is considered critical to the development of the domestic research and towards internationalization.

As has been shown in previous papers (Aleixandre, Aleixandre-Tudó, Bolaños-Pizarro, \& Aleixandre-Benavent, 2013; Aleixandre-Benavent, Aleixandre-Tudó, González alcaide, \& Aleixandre, 2013) and in other research areas such us 
nanobiopharmaceuticals (Qingjun $\unrhd$ o, 2011) alcoholism and health (Murray, 2011) or biotechnology (Suarez-Villa, 2004) United States is the chosen country to collaborate with by both the developed and the emerging countries. It is precisely the emerging countries and countries with fewer resources the ones who have a higher percentage of papers published in collaboration, simply because they need to use the available resources present in the more developed countries. When choosing countries with which establish collaboration there is also an important cultural roots influence. For this reason, Spain has a preference to collaborate with Latin American countries, such us Argentina and Chile, while Portugal does with Brazil.

With respect to the most cited papers, we highlight the significance of the research on the hypothetical health benefits from wine, especially red wine, attributed to the polyphenols, particularly flavonoids and resveratrol antioxidant and anti-inflammatory effects. These health benefits are related to the prevention of several pathologies as cancer, cardiovascular diseases and atherosclerosis, among others (Aleixandre, Aleixandre-Tudó, Bolaños-Pizarro, Aleixandre-Benavent, 2013). It is noteworthy that most of these highly-cited papers have been published in journals of general purpose with high impact factor, such as Science, PloS One, as well as biomedical journals and highly-cited specific journals related with food science and technology. Obviously the number of citations in published papers is higher in the early years of the studied period, as they are available longer time to be cited.

This work also has some limitations that should be considered. The SCIE does not contain all of the published scientific papers on viticulture and oenology, so other bibliographic databases could have been used complementarily. Nevertheless, we used the SCIE because it includes the most important journals in the world, which helps emphasis analyses on the most relevant papers. On the other hand, it provides the names of all institutional affiliations of the authors, which allowed us to determine the indicators of collaboration between countries. Moreover, it makes the number of citations that articles have received available, information that does not exist in other databases.

\section{Conclusion}

This study provides an indication of the state of collaborative research between old world and new world wine producing countries in the field of viticulture and enology based on the analysis of articles published in journals included in the SCIE. The results highlight the significant growth in the number of research pape $Q_{1}$ ublished from 1994 to 2013. All countries have USA as the main co y with which collaborates with and, in second place, countries with which they bind cultural or linguistic ties. Future work could identify the evolution of collaboration over time and new collaborations with other emerging countries such us China, India or Russia. 


\section{References}

Aleixandre, J.L., Aleixandre-Tudó, J.L., Bolaños-Pizarro, M., \& Aleixandre-Benavent, R. (2013). Mapping the Scientific Research on Wine and Health (2001-2011). Journal of Agricultural and Food Chemistry, 61 (49), 11871-11880.

Aleixandre-Benavent, R., Aleixandre-Tudó, J.L., Gonzaléz Alcaide, G., \& Aleixandre, J.L. (2013). Analysis of the collaboration between the USA and the EU in viticulture and oenology. Italian Journal of Food Science, 25, 1-13.

Anderson, K., Norman, D., \& Wittwer, G. (2003). Globalization of the World's Wine Markets", The World Economy, 26(5), 659-87.

Anderson, K. (2003). Wine's new world. Foreign Policy (Carnegie Endowment Intl Peace) 136: pp. 47-54.

Archibugi, D. (2007). Introduction to the Special Issue on Knowledge and Innovation in the Globalizing World Wine Industry. International Journal of Technology and Globalization, Vol.3 (2-3), 125-126.

Aylward, D. K. (2003). A Documentary of Innovation Support among New World Wine Industrie, Journal of Wine Research, 14 (1), 31-43

Beaver D., \& Rosen R. (1979.) Studies in scientific collaboration. Part II. Scientific coauthorship, research productivity and visibility in the French elite. Scientometrics, 1, 133-149.

Benfratello, L., Piacenza, M., \& Sacchettos, S. (2009). Taste or reputation: What drives market prices in the wine industry?. Applied Economics, 41(17), 2197-2209.

Beverland, M. (2006). The 'real thing': branding authenticity in the luxury wine trade. Journal of Business Research, 59, 251-258.

Bramley, C., \& Kirsten, J.F. (2007). Exploring the economic rationale for protecting geographical indicators in agriculture. Agrekon, 46 (1), 69-93.

Brown, E., Derudder, B., Parnreiter, C.H., Pelupessy, W., Taylor, P.J., \& Witlox, F. (2010). World city networks and global commodity chains: towards a world-system's integration. Global Networks: A Journal of Transnational Affairs. Vol. 10 (1), 12-34.

Campbell, G., \& Guibert, N. (2006). Old World strategies against New World competition in a globalising wine industry. British Food Journal, 108 (4), 233-242.

Carew, R., \& Florkowski, W. J. (2010). The importance of geographic wine appellations: hedonic pricing of burgundy wines in the British Columbia wine Market. Canadian Journal of Agricultural Economics, 58, 93-108.

Cassi L., Morrison A., \& Rabellotti R. (2011). The changing geography of science in wine: evidence from emerging countries, in Giuliani E., A. Morrison and R. Rabellotti 
(Eds.) Innovation and Technological Catch-Up: The Changing Geography of Wine Production, Edward Elgar: Cheltenham.

Duarte, A., \& Northcote, J. (2009). Wine, history, landscape: origin branding in Western Australia. British Food Journal, 111(11), 1248-1259.

Katz, J.S., \& Martin, B.R. (1997). What is research collaboration? Research Policy, 26 (1), $1-18$

Garnier, N., Richardin, P., Cheynier, V., \& Regert, M. (2003). Characterization of thermally assisted hydrolysis and methylation products of polyphenols from modern and archaeological vine derivatives using gas chromatography-mass spectrometry. Analytica Chimica Acta, 493 (2), 137-157.

Gil, J.M., \& Sánchez, M. (1997). Consumer preferences for wine attributes: a conjoint approach. British Food Journal, 99 (1), 3-11.

Glänzel, W., \& Veugelers, R. (2006). Science for wine: a bibliometric assessment of wine and grape research for wine-producing and consuming Countries. American Journal of Enology and Viticulture, 57 (1), 23-32.

Glänzel, W. (2001). National characteristics in international scientific co-authorship relations. Scientometrics, 51 (1), 69-115.

González-Alcaide, G., Aleixandre-Benavent, R., Navarro-Molina, C., \& ValderramaZurián, J.C. (2008a) 'Coauthorship networks and institutional collaboration patterns in reproductive biology',. Fertility and Sterility, 90, 941-56.

Gonzalez-Alcaide, G., Alonso Arroyo, A., Gonzalez de Dios, J., Perez Sempere, A., Valderrama Zurian, J.C., \& R. Aleixandre-Benavent, R. (2008b). Coauthorship networks and institutional collaboration in Revista de Neurología. Revista de Neurologia, 46, 642-651.

Katz, J.S., \& Martin, B. R. (1997). What is research collaboration?, Research Policy, 26 (1), 1-18.

Lecocq, S., \& Visser, M. (2006). What determines wine prices: objective vs sensory characteristics. Journal of Wine Economics. 1(1), 42-56.

Luukkonen, T., Persson, O., \& Sivertsen G. (1992). Understanding patterns of international scientific collaboration. Science, Technology and Human Values. 17, 101126.

Murray, M. M. (2011). The role of the NIH in response to the global burden of alcohol and health: opportunities for usa-european collaboration. Alcohol and Alcoholism, 46 (1), 25-25.

Newman, M.E.J. (2004). Coauthorship networks and patterns of scientific collaboration. Proceedings of the National Academy of Science of the USA, 101, 5200-5205. 
Parcero, O. J., \& Villanueva, E. (2011). World wine exports: what determines the success of new world wine producers?.American Association of Wine Economists. Working Paper $\mathrm{N}^{\circ}$ 87. 26 p.

Peled, A. (2011). When Transparency and Collaboration Collide: The USA Open Data Program. Journal of the American Society for Information Science and Technology, 62 (11), 2085-2094.

Perrouty, J.P., d'Hauteville, F., \& Lockshin, L. (2007). The influence of wine attributes on region of origin equity: an analysis of the moderating effect of consumer's perceived expertise. Agribusiness, 22 (3), 323-41.

Qingjun, Z., \& Jiancheng, G. (2011). International collaboration of three 'giants' with the G7 countries in emerging nanobiopharmaceuticals. Scientometrics, 87 (1), 159-170.

Robinson, J. (2006). El Origen del vino en el nuevo mundo. The Oxford Companion to Wine ( $3^{\mathrm{a}}$ edición). Oxford University Press.

Schamel, G. (2006). Geography versus brands in a global wine market. Agribusiness. 22(3), 363-374.

Lao, Sip Shervin (2009). Old World vs. New World wines, Manilla Standard Today.

Suarez-Villa, L. (2004). Collaboration in biotechnology: how inter-firm relations strengthen research efforts in the USA. International Journal of Technology Management, 27 (5), 452-464.

Subramanyam, K. (1983). Bibliometric studies of research collaboration: A review. Journal of Information Science January, 6 (1), 33-38.

Yoo, V., Florkowski, W. J., \& Crew, R. (2011). Pricing attributes of wines from emerging suppliers on the British Columbia market. Agricultural and Applied Economics Association 2011 Annual Meeting, July 24-26, Pittsburh, Pennsylvania. 20 p. 
TABLE 1. Journals with more tan 5 papers published

\begin{tabular}{|l|c|c|c|c|c|}
\hline \multicolumn{1}{|c|}{ JOURNAL } & $\mathbf{1 9 9 4 - 1 9 9 8}$ & $\mathbf{1 9 9 9 - 2 0 0 3}$ & $\mathbf{2 0 0 4 - 2 0 0 8}$ & $\mathbf{2 0 0 9 - 2 0 1 3}$ & TOTAL \\
\hline JOURNAL OF AGRICULTURAL AND FOOD CHEMISTRY & 5 & 25 & 28 & 45 & 103 \\
\hline AMERICAN JOURNAL OF ENOLOGY AND VITICULTURE & 19 & 15 & 25 & 12 & 71 \\
\hline VITIS & 16 & 14 & 10 & 8 & 48 \\
\hline AUSTRALIAN JOURNAL OF GRAPE AND WINE RESEARCH & 0 & 5 & 5 & 18 & 28 \\
\hline FOOD CHEMISTRY & 0 & 3 & 4 & 21 & 28 \\
\hline JOURNAL INTERNATIONAL DES SCIENCES DE LA VIGNE ET DU VIN & 0 & 5 & 12 & 9 & 26 \\
\hline FOOD QUALITY AND PREFERENCE & 0 & 2 & 8 & 11 & 21 \\
\hline ANALYTICA CHIMICA ACTA & 1 & 5 & 7 & 5 & 18 \\
\hline APPLIED AND ENVIRONMENTAL MICROBIOLOGY & 1 & 3 & 10 & 3 & 17 \\
\hline PHYTOPATHOLOGY & 5 & 3 & 6 & 3 & 17 \\
\hline BMC PLANT BIOLOGY & 0 & 0 & 2 & 14 & 16 \\
\hline JOURNAL OF CHROMATOGRAPHY A & 1 & 4 & 5 & 6 & 16 \\
\hline FOOD RESEARCH INTERNATIONAL & 0 & 0 & 0 & 14 & 14 \\
\hline JOURNAL OF APPLIED MICROBIOLOGY & 2 & 2 & 8 & 1 & 13 \\
\hline THEORETICAL AND APPLIED GENETICS & 0 & 4 & 7 & 2 & 13 \\
\hline WATER SCIENCE AND TECHNOLOGY & 0 & 0 & 11 & 2 & 13 \\
\hline INTERNATIONAL JOURNAL OF FOOD MICROBIOLOGY & 0 & 1 & 5 & 6 & 12 \\
\hline JOURNAL OF THE SCIENCE OF FOOD AND AGRICULTURE & 2 & 2 & 1 & 7 & 12 \\
\hline PLANT DISEASE & 3 & 1 & 3 & 5 & 12 \\
\hline EUROPEAN FOOD RESEARCH AND TECHNOLOGY & 0 & 0 & 3 & 8 & 11 \\
\hline PLANT PATHOLOGY & 2 & 2 & 1 & 5 & 10 \\
\hline PLOS ONE & 0 & 0 & 1 & 9 & 10 \\
\hline BMC GENOMICS & 0 & 0 & 1 & 8 & 9 \\
\hline EUROPEAN JOURNAL OF PLANT PATHOLOGY & 1 & 1 & 3 & 4 & 9 \\
\hline JOURNAL OF EXPERIMENTAL BOTANY & 0 & 0 & 4 & 5 & 9 \\
\hline SOUTH AFRICAN JOURNAL OF ENOLOGY AND VITICULTURE & 0 & 0 & 2 & 7 & 9 \\
\hline
\end{tabular}




\begin{tabular}{|c|c|c|c|c|c|}
\hline TALANTA & 0 & 2 & 2 & 5 & 9 \\
\hline WORLD JOURNAL OF MICROBIOLOGY \& BIOTECHNOLOGY & 0 & 0 & 4 & 5 & 9 \\
\hline AMERICAN JOURNAL OF CLINICAL NUTRITION & 4 & 1 & 2 & 1 & 8 \\
\hline ARCHIVES OF VIROLOGY & 0 & 2 & 4 & 2 & 8 \\
\hline FEMS MICROBIOLOGY LETTERS & 1 & 3 & 3 & 1 & 8 \\
\hline JOURNAL OF CARDIOVASCULAR PHARMACOLOGY & 1 & 3 & 2 & 2 & 8 \\
\hline AGRICULTURAL AND FOREST METEOROLOGY & 0 & 1 & 2 & 4 & 7 \\
\hline ANNALS OF MICROBIOLOGY & 0 & 0 & 3 & 4 & 7 \\
\hline INTERNATIONAL JOURNAL OF FOOD SCIENCE AND TECHNOLOGY & 0 & 2 & 0 & 5 & 7 \\
\hline LETTERS IN APPLIED MICROBIOLOGY & 1 & 0 & 2 & 4 & 7 \\
\hline PHYTOPATHOLOGIA MEDITERRANEA & 0 & 0 & 0 & 7 & 7 \\
\hline SCIENTIA HORTICULTURAE & 1 & 1 & 1 & 4 & 7 \\
\hline ADDICTION & 0 & 2 & 2 & 2 & 6 \\
\hline ANALYTICAL AND BIOANALYTICAL CHEMISTRY & 0 & 1 & 2 & 3 & 6 \\
\hline ANALYTICAL CHEMISTRY & 1 & 0 & 2 & 3 & 6 \\
\hline BRITISH JOURNAL OF NUTRITION & 0 & 1 & 2 & 3 & 6 \\
\hline CARBOHYDRATE POLYMERS & 1 & 4 & 0 & 1 & 6 \\
\hline FOOD AND CHEMICAL TOXICOLOGY & 0 & 1 & 1 & 4 & 6 \\
\hline FOOD MICROBIOLOGY & 1 & 1 & 2 & 2 & 6 \\
\hline PHYTOCHEMISTRY & 1 & 1 & 2 & 2 & 6 \\
\hline PRECISION AGRICULTURE & 0 & 0 & 2 & 4 & 6 \\
\hline
\end{tabular}


TABLE 2. Main subject areas, key words, journals and countries

\begin{tabular}{|c|c|c|c|c|c|c|}
\hline WOS Subject Category & Articles & Key Words & Articles & Journals & Articles & $\begin{array}{c}\text { Countries } \\
\text { and } \\
\text { Articles* }\end{array}$ \\
\hline \multirow{3}{*}{ Food Science \& Technology } & \multirow{3}{*}{430} & RED WINES & 79 & JOURNAL OF AGRICULTURAL AND FOOD CHEMISTRY & 103 & \multirow{3}{*}{$\begin{array}{l}\text { France }(n=154) \\
\text { USA }(n=153) \\
\text { Spain }(n=105)\end{array}$} \\
\hline & & VITIS-VINIFERA L & 52 & AMERICAN JOURNAL OF ENOLOGY AND VITICULTURE & 71 & \\
\hline & & WINES & 46 & FOOD CHEMISTRY & 28 & \\
\hline \multirow{3}{*}{ Horticulture } & \multirow{3}{*}{222} & VITIS-VINIFERA L & 45 & AMERICAN JOURNAL OF ENOLOGY AND VITICULTURE & 71 & \multirow{3}{*}{$\begin{array}{l}\text { USA (106) } \\
\text { France (90) } \\
\text { Italy (57) }\end{array}$} \\
\hline & & IDENTIFICATION & 23 & VITIS & 48 & \\
\hline & & GRAPEVINES & 19 & AUSTRALIAN JOURNAL OF GRAPE AND WINE RESEARCH & 28 & \\
\hline \multirow{3}{*}{ Biotechnology \& Applied Microbiology } & \multirow{3}{*}{208} & IDENTIFICATION & 29 & AMERICAN JOURNAL OF ENOLOGY AND VITICULTURE & 71 & \multirow{3}{*}{$\begin{array}{l}\text { USA (104) } \\
\text { France (64) } \\
\text { Spain (62) }\end{array}$} \\
\hline & & SACCHAROMYCES-CEREVISIAE & 22 & APPLIED AND ENVIRONMENTAL MICROBIOLOGY & 17 & \\
\hline & & VITIS-VINIFERA L & 22 & JOURNAL OF APPLIED MICROBIOLOGY & 13 & \\
\hline \multirow{3}{*}{ Plant Sciences } & \multirow{3}{*}{192} & VITIS-VINIFERA L. & 41 & PHYTOPATHOLOGY & 17 & \multirow{3}{*}{$\begin{array}{l}\text { USA (105) } \\
\text { France (67) } \\
\text { Australia (57) }\end{array}$} \\
\hline & & ARABIDOPSIS-THALIANA & 26 & BMC PLANT BIOLOGY & 16 & \\
\hline & & IDENTIFICATION & 22 & THEORETICAL AND APPLIED GENETICS & 13 & \\
\hline \multirow{3}{*}{ Chemistry, Applied } & \multirow{3}{*}{166} & RED WINES & 53 & JOURNAL OF AGRICULTURAL AND FOOD CHEMISTRY & 103 & \multirow{3}{*}{$\begin{array}{l}\text { USA (57) } \\
\text { France (54) } \\
\text { Spain (44) }\end{array}$} \\
\hline & & WHITE WINES & 22 & FOOD CHEMISTRY & 28 & \\
\hline & & IDENTIFICATION & 21 & JOURNAL OF THE SCIENCE OF FOOD AND AGRICULTURE & 12 & \\
\hline \multirow{3}{*}{ Agriculture, Multidisciplinary } & \multirow{3}{*}{144} & RED WINES & 31 & JOURNAL OF AGRICULTURAL AND FOOD CHEMISTRY & 103 & \multirow{3}{*}{$\begin{array}{l}\text { USA (50) } \\
\text { France (42) } \\
\text { Spain (40) }\end{array}$} \\
\hline & & IDENTIFICATION & 18 & JOURNAL OF THE SCIENCE OF FOOD AND AGRICULTURE & 12 & \\
\hline & & WINES & 14 & PRECISION AGRICULTURE & 6 & \\
\hline \multirow{3}{*}{ Microbiology } & \multirow{3}{*}{109} & IDENTIFICATION & 22 & APPLIED AND ENVIRONMENTAL MICROBIOLOGY & 17 & \multirow{3}{*}{$\begin{array}{l}\text { USA (43) } \\
\text { Spain (38) } \\
\text { Italy (31) }\end{array}$} \\
\hline & & STRAINS & 17 & JOURNAL OF APPLIED MICROBIOLOGY & 13 & \\
\hline & & FERMENTATIONS & 16 & INTERNATIONAL JOURNAL OF FOOD MICROBIOLOGY & 12 & \\
\hline \multirow{2}{*}{ Chemistry, Analytical } & \multirow{2}{*}{90} & WINES & 23 & AMERICAN LABORATORY & 1 & \multirow{2}{*}{$\begin{array}{l}\text { Spain (27) } \\
\text { USA (25) }\end{array}$} \\
\hline & & RED WINES & 16 & ANALUSIS & 1 & \\
\hline
\end{tabular}




\begin{tabular}{|c|c|c|c|c|c|c|}
\hline & & IDENTIFICATION & 10 & ANALYST & 3 & France (22) \\
\hline \multirow{3}{*}{ Agronomy } & \multirow{3}{*}{75} & VITIS-VINIFERA L. & 14 & THEORETICAL AND APPLIED GENETICS & 13 & \multirow{3}{*}{$\begin{array}{l}\text { USA (39) } \\
\text { France (28) } \\
\text { Spain (26) }\end{array}$} \\
\hline & & IDENTIFICATION & 11 & PLANT PATHOLOGY & 10 & \\
\hline & & GRAPEVINES & 9 & EUROPEAN JOURNAL OF PLANT PATHOLOGY & 9 & \\
\hline \multirow{3}{*}{ Nutrition \& Dietetics } & \multirow{3}{*}{73} & RED WINES & 29 & FOOD CHEMISTRY & 28 & \multirow{3}{*}{$\begin{array}{l}\text { USA (42) } \\
\text { Italy (20) } \\
\text { Spain (16) }\end{array}$} \\
\hline & & RISK & 9 & AMERICAN JOURNAL OF CLINICAL NUTRITION & 8 & \\
\hline & & WHITE WINES & 8 & BRITISH JOURNAL OF NUTRITION & 6 & \\
\hline \multirow{3}{*}{ Biochemistry \& Molecular Biology } & \multirow{3}{*}{72} & RED WINES & 17 & PHYTOCHEMISTRY & 6 & \multirow{3}{*}{$\begin{array}{l}\text { USA (50) } \\
\text { Italy (28) } \\
\text { France (23) }\end{array}$} \\
\hline & & EXPRESSION & 9 & PLANT SCIENCE & 5 & \\
\hline & & VITIS-VINIFERA L & 7 & FREE RADICAL RESEARCH & 4 & \\
\hline
\end{tabular}

* Countries with most published articles in the subject area 
TABLE 3. Papers published in collaboration between Old World and New World wine producing countries

\begin{tabular}{|c|c|c|c|c|c|c|c|c|c|c|c|c|c|c|}
\hline \multirow[b]{2}{*}{ OLD EUROPE } & \multicolumn{14}{|c|}{ NEW WORLD } \\
\hline & Argentina & Australia & Brazil & Canada & Chile & Mexico & $\begin{array}{c}\text { New } \\
\text { Zealand }\end{array}$ & Peru & $\begin{array}{l}\text { South } \\
\text { Africa }\end{array}$ & Uruguay & USA & $\begin{array}{c}\text { Total } \\
\text { collab } \\
\text { oratio } \\
\text { ns } \\
\end{array}$ & $\begin{array}{c}\text { Total } \\
\text { article } \\
\mathrm{s} \\
\end{array}$ & $\begin{array}{c}\% \\
\text { collab } \\
\text { oratio } \\
\text { ns } \\
\end{array}$ \\
\hline Austria & 1 & 6 & 4 & 2 & 0 & 2 & 2 & 0 & 0 & 0 & 29 & 46 & 386 & 11.9 \\
\hline Bulgaria & 0 & 0 & 0 & 0 & 0 & 0 & 0 & 0 & 0 & 0 & 11 & 11 & 117 & 9.4 \\
\hline France & 24 & 98 & 40 & 49 & 42 & 28 & 19 & 0 & 25 & 11 & 193 & 529 & 3.699 & 14.3 \\
\hline Germany & 6 & 46 & 8 & 34 & 10 & 4 & 6 & 1 & 16 & 1 & 128 & 260 & 1.804 & 14.4 \\
\hline Greece & 0 & 2 & 0 & 14 & 0 & 0 & 0 & 0 & 0 & 0 & 37 & 53 & 651 & 8.1 \\
\hline Hungary & 2 & 3 & 1 & 5 & 1 & 0 & 0 & 0 & 3 & 0 & 57 & 72 & 391 & 18.4 \\
\hline Italy & 18 & 53 & 21 & 25 & 10 & 8 & 12 & 1 & 15 & 7 & 235 & 405 & 3.791 & 10.7 \\
\hline \begin{tabular}{|l|} 
Portugal \\
\end{tabular} & 2 & 7 & 27 & 3 & 2 & 1 & 0 & 0 & 8 & 1 & 27 & 78 & 1.204 & 6.5 \\
\hline Romania & 1 & 0 & 1 & 3 & 0 & 0 & 0 & 0 & 1 & 0 & 5 & 11 & 246 & 4.5 \\
\hline Spain & 51 & 48 & 29 & 12 & 48 & 25 & 6 & 7 & 17 & 12 & 117 & 372 & 4.786 & 7.8 \\
\hline Switzerland & 2 & 12 & 2 & 15 & 0 & 1 & 6 & 0 & 10 & 0 & 67 & 115 & 522 & 22 \\
\hline Total collaborations & 107 & 275 & 133 & 162 & 113 & 69 & 51 & 9 & 95 & 32 & 906 & & & \\
\hline Total articles & 388 & 1,973 & 1,089 & 876 & 458 & 196 & 366 & 16 & 577 & 85 & 5,837 & & & \\
\hline$\%$ collaborations & 30.2 & 13.9 & 12.2 & 18.5 & 24.7 & 35.2 & 13.9 & 56.3 & 16.5 & 37.6 & 15.5 & & & \\
\hline
\end{tabular}


TABLE 4. Most cited papers

\begin{tabular}{|c|c|c|c|}
\hline AUTHORS & TITTLE & SOURCE & $\begin{array}{l}\text { TIMES } \\
\text { CITED }\end{array}$ \\
\hline $\begin{array}{l}\text { Jang M, Cai L, Udeani GO, Slowing KV, } \\
\text { Thomas CF, Beecher CW, Fong HH, } \\
\text { Farnsworth NR, Kinghorn AD, Mehta RG, } \\
\text { Moon RC, Pezzuto JM. }\end{array}$ & Cancer chemopreventive activity of resveratrol, a natural product derived from grapes & Science $1997 ; 275(5297): 218-20$. & 2,644 \\
\hline $\begin{array}{l}\text { Singleton VL, Orthofer R, Lamuela- } \\
\text { Raventos RM. }\end{array}$ & $\begin{array}{l}\text { Analysis of total phenols and other oxidation substrates and antioxidants by means of Folin- } \\
\text { Ciocalteu reagent }\end{array}$ & $\begin{array}{l}\text { OXIDANTS AND ANTIOXIDANTS, PT } \\
\text { A1999; 299:152-178. }\end{array}$ & 2,348 \\
\hline $\begin{array}{l}\text { Gil MI, Tomás-Barberán FA, Hess-Pierce } \\
\text { B, Holcroft DM, Kader AA. }\end{array}$ & $\begin{array}{l}\text { Antioxidant activity of pomegranate juice and its relationship with phenolic composition and } \\
\text { processing }\end{array}$ & $\begin{array}{l}\text { J Agric Food Chem 2000; 48(10):4581- } \\
\text { 9. }\end{array}$ & 624 \\
\hline $\begin{array}{l}\text { Willett WC, Sacks F, Trichopoulou A, } \\
\text { Drescher G, Ferro-Luzzi A, Helsing E, } \\
\text { Trichopoulos D. }\end{array}$ & Mediterranean diet pyramid: a cultural model for healthy eating. & $\begin{array}{l}\text { Am J Clin Nutr 1995; } 61(6 \\
\text { Suppl):1402S-1406S. }\end{array}$ & 561 \\
\hline $\begin{array}{l}\text { Kris-Etherton PM, Hecker KD, Bonanome } \\
\text { A, et al. }\end{array}$ & Bioactive compounds in foods: Their role in the prevention of cardiovascular disease and cancer & $\begin{array}{l}\text { American Journal of Medicine 2002; } \\
113(9 \mathrm{~b} \text { Suppl):71-88. }\end{array}$ & 384 \\
\hline Velasco R, Zharkikh A, Troggio M, et al. & A high quality draft consensus sequence of the genome of a heterozygous grapevine variety. & PLoS One 2007; 19;2(12):e1326. & 373 \\
\hline $\begin{array}{l}\text { Compant S, Duffy B, Nowak J, Clément C, } \\
\text { Barka EA. }\end{array}$ & $\begin{array}{l}\text { Use of plant growth-promoting bacteria for biocontrol of plant diseases: Principles, mechanisms of } \\
\text { action, and future prospects }\end{array}$ & $\begin{array}{l}\text { Appl Environ Microbiol 2005; } \\
71(9): 4951-9 .\end{array}$ & 371 \\
\hline Duran N, Rosa MA, D'Annibale A, et al. & $\begin{array}{l}\text { Applications of laccases and tyrosinases (phenoloxidases) immobilized on different supports: a } \\
\text { review }\end{array}$ & $\begin{array}{l}\text { Enzyme Microb Technol 2002; } \\
\text { 31(7):907-931. }\end{array}$ & 343 \\
\hline $\begin{array}{l}\text { Teissedre PL, Frankel EN, Waterhouse AL, } \\
\text { et al. }\end{array}$ & Inhibition of in vitro human LDL oxidation by phenolic antioxidants from grapes and wines & J Sci Food Agric 1996; 70(1):55-61. & 326 \\
\hline Yao LH, Jiang YM, Shi J, et al. & Flavonoids in food and their health benefits & $\begin{array}{l}\text { Plant Foods Hum Nutr 2004; 59(3):113- } \\
122 .\end{array}$ & 287 \\
\hline Ray PS, Maulik G, Cordis GA, et al. & The red wine antioxidant resveratrol protects isolated rat hearts from ischemia reperfusion injury & $\begin{array}{l}\text { Free Radic Biol Med 1999; 27(1- } \\
\text { 2):160-9. }\end{array}$ & 253 \\
\hline Zang M, Xu S, Maitland-Toolan KA, et al. & $\begin{array}{l}\text { Polyphenols stimulate AMP-activated protein kinase, lower lipids, and inhibit accelerated } \\
\text { atherosclerosis in diabetic LDL receptor-deficient mice }\end{array}$ & Diabetes 2006; 55(8):2,180-2,191. & 241 \\
\hline Tapiero H, Tew KD, Ba GN, et al. & Polyphenols: do they play a role in the prevention of human pathologies? & $\begin{array}{l}\text { Biomed Pharmacother 2002;56(4):200- } \\
7 .\end{array}$ & 230 \\
\hline Vogt $\mathrm{T}$, Jones $\mathrm{P}$. & Glycosyltransferases in plant natural product synthesis: characterization of a supergene family & Trends Plant Sci 2000;5(9):380-386. & 226 \\
\hline Lee IM, Bertaccini A, Vibio M, et al. & Detection of Multiple Phytoplasmas In Perennial Fruit-Trees With Decline Symptoms In Italy & Phytopathology 1995; 85(6):728-735. & 224 \\
\hline German JB, Walzem RL. & The health benefits of wine & Annu Rev Nutr 2000; 20:561-593. & 220 \\
\hline Casper RF, Quesne M, Rogers IM, et al. & $\begin{array}{l}\text { Resveratrol has antagonist activity on the aryl hydrocarbon receptor: Implications for prevention of } \\
\text { dioxin toxicity }\end{array}$ & Mol Pharmacol 1999; 56(4):784-90. & 213 \\
\hline $\begin{array}{l}\text { Tomás-Barberán FA, Gil MI, Cremin P, et } \\
\text { al. }\end{array}$ & HPLC-DAD-ESIMS analysis of phenolic compounds in nectarines, peaches, and plums & $\begin{array}{l}\text { J Agric Food Chem 2001; 49(10):4748- } \\
60 .\end{array}$ & 212 \\
\hline
\end{tabular}


FIG. 1. Annual evolution of papers published in collaboration between Old World and New World

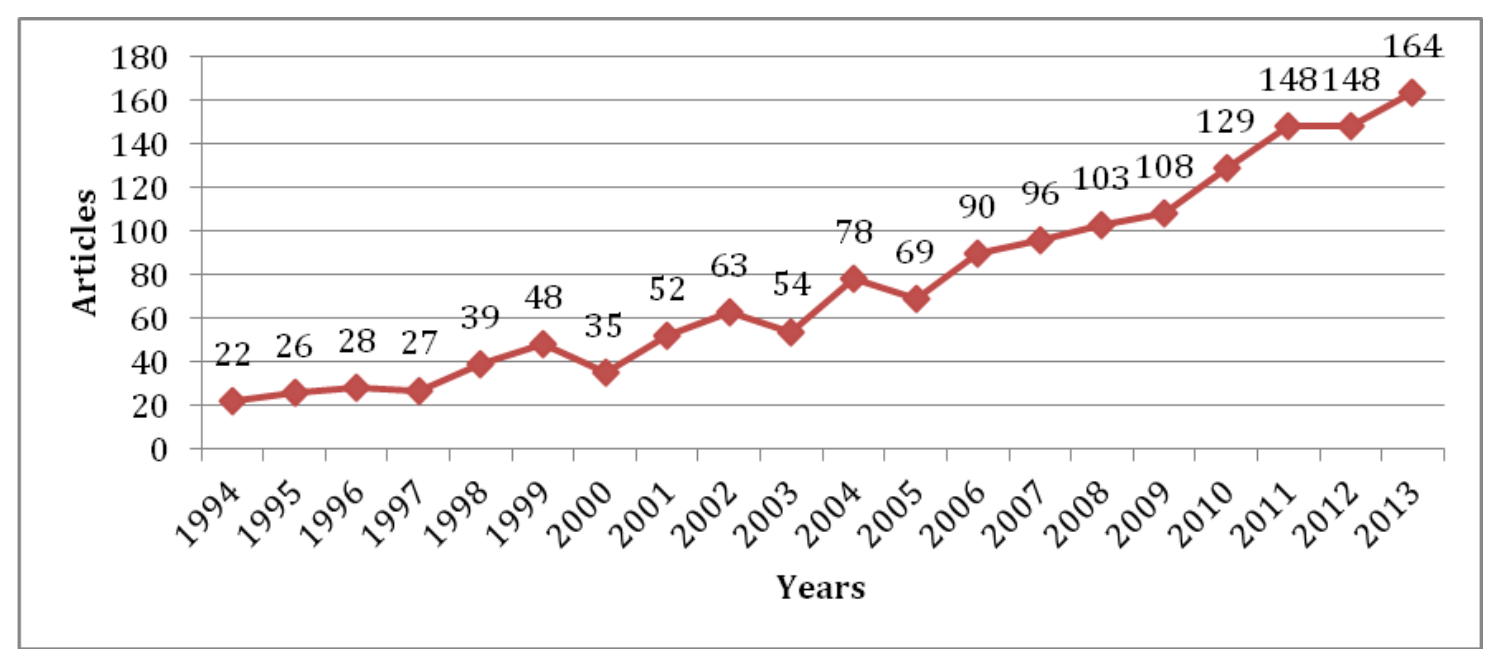


FIG. 2. Collaboration network between countries

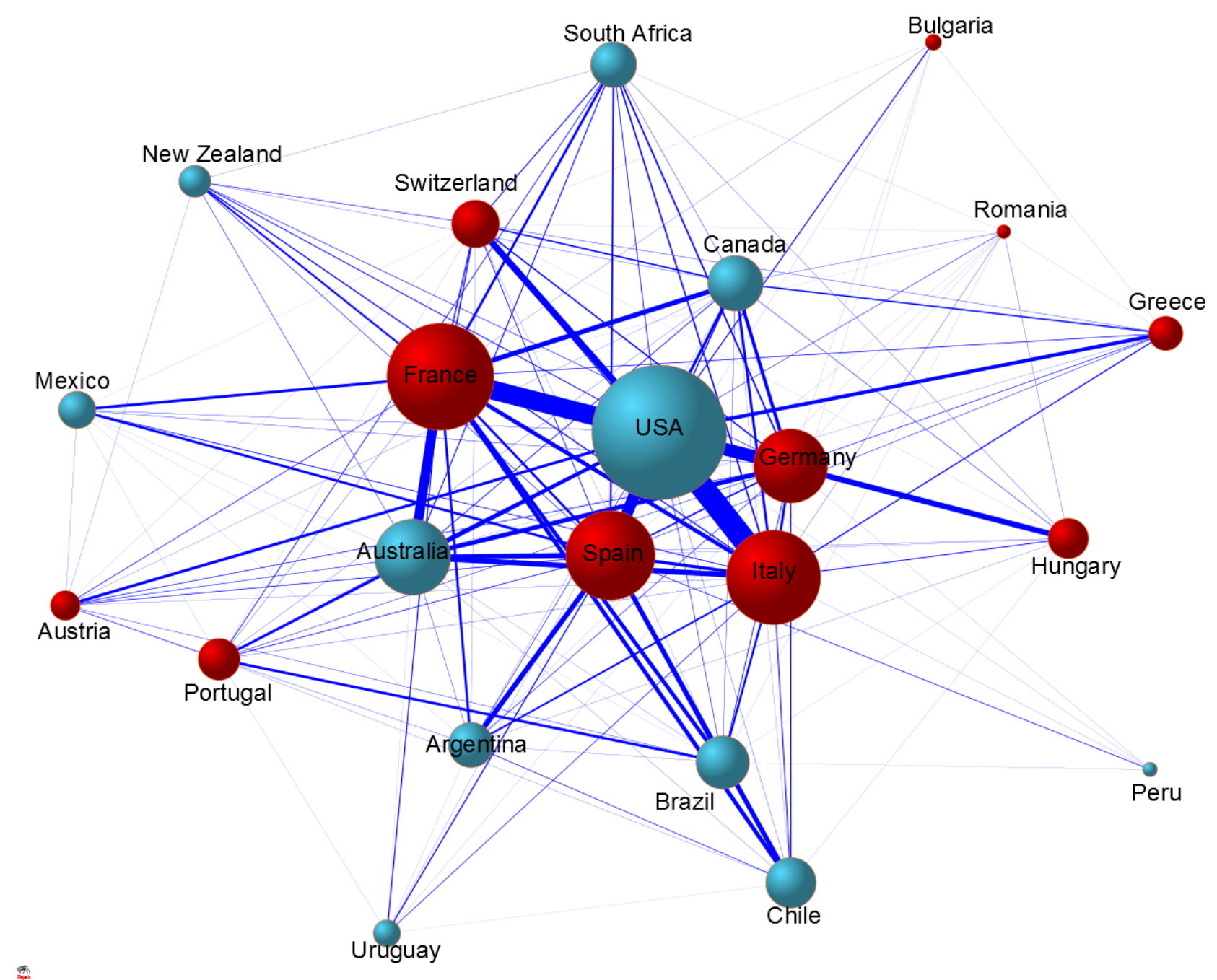


FIG. 3. Correlation between the number of published papers and the number of received citations in the two groups of countries
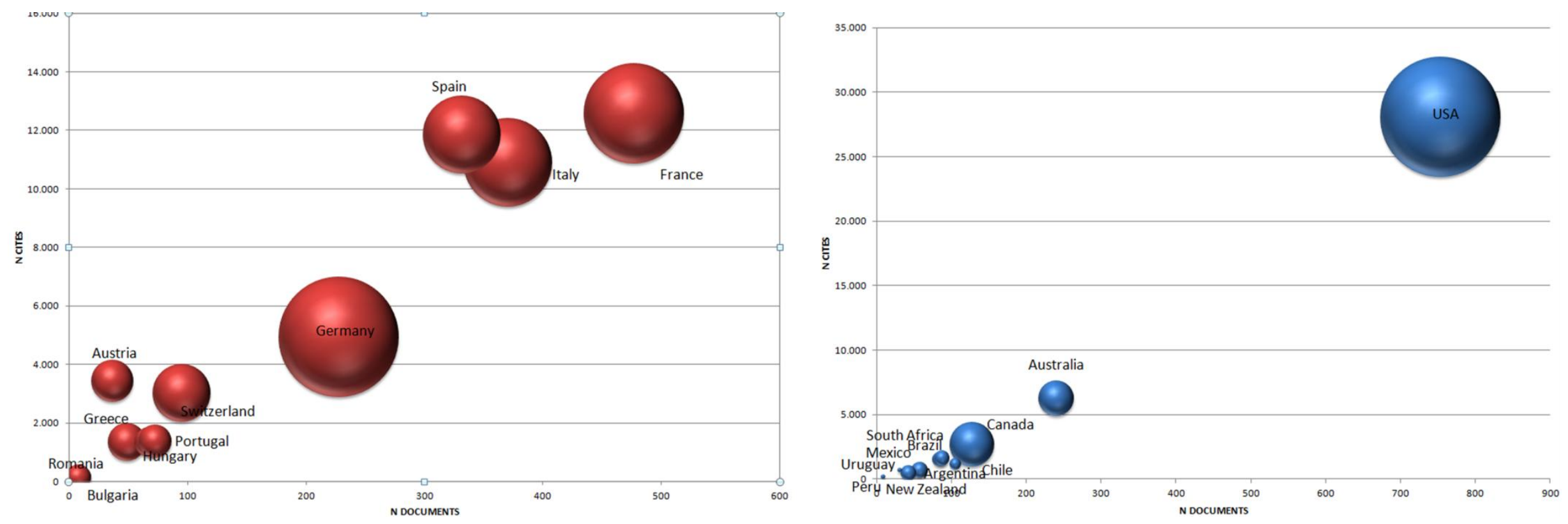